\title{
Family labor supply, taxation and saving in an imperfect capital market
}

\author{
Patricia Apps • Ray Rees
}

Received: 17 July 2009/Accepted: 20 March 2010/Published online: 8 April 2010

(C) The Author(s) 2010. This article is published with open access at Springerlink.com

\begin{abstract}
This paper combines income and expenditure with time use data to provide a unique picture of the labor supply, household production, saving and consumption decisions of two-adult households over a life cycle defined in terms of the presence and ages of children. The study also draws on data for household borrowing and lending, direct and indirect benefits and taxes to calibrate a "family" life cycle model at the core of which is the hypothesis that households face a borrowing interest rate that rises with the amount of non-collateral based borrowing. The household members jointly choose time paths of time use, consumption and saving over their life cycle in the face of this capital market imperfection. Importantly, households are shown to differ significantly in their saving behavior in a way that depends on secondary earner labor supply, with a strong positive association between saving and the income of the second earner. The results differ sharply from those of the existing literature.
\end{abstract}

Keywords Life cycle - Female labor supply - Taxation - Saving ·

Time allocation $\cdot$ Household production $\cdot$ Child care $\cdot$ Imperfect capital market

JEL Classification D13 $\cdot \mathrm{D} 91 \cdot \mathrm{H} 31 \cdot \mathrm{J} 2$

\footnotetext{
P. Apps $(\bowtie)$

University of Sydney Law School, Sydney, NSW, Australia

e-mail: patricia.apps@sydney.edu.au

R. Rees

University of Munich, Munich, Germany

e-mail: ray.rees@1rz.uni-muenchen.de
} 


\section{Introduction}

The main preoccupation of the literature on consumption choice over the life cycle has been the "excess sensitivity puzzle". This puzzle arose out of household expenditure survey data that showed household consumption expenditure tracking income over the life cycle in a way that is hard to reconcile with the premise that the capital market allows the household to decouple its consumption and income paths. The leading contenders for resolution of this puzzle seem to be: precautionary or buffer-stock saving; ${ }^{2}$ liquidity constraints in the extreme form of the complete absence of borrowing possibilities; ${ }^{3}$ and demographic effects, especially the presence of children. ${ }^{4}$

However, the modelling approach adopted in these studies fails to take account of one of the single most important socio-economic developments over the last half century, the large expansion in female labor supply overall, with at the same time considerable heterogeneity across households in this respect. In many OECD countries, for example the US, UK, Germany and Australia, the labor supply of prime aged married women is now around half that of married men in the same age category and highly heterogeneous across households with similar demographic characteristics and wage rates.

These observations have far-reaching implications for the household's labor supply and income generation process and for its consumption and saving decisions which are completely missed by the standard model, because of the convention of treating the family as a single person ${ }^{5}$ and the failure to recognise household production as a close substitute for female labor supply after (though not before) the arrival of children.

In this paper we combine time use and household expenditure survey data for Australia to show that it is essential to take account of the multi-person nature of the household and the allocation of time to household production by the female partner, as the second earner in the large majority of households. When we expand the data set to include the household's non-market time allocation decisions, we see that it precisely because of the level and across-household variation in female labor supply that the assumption of a single person household with an exogenous process of household income determination is no longer sustainable. In other words, possible exogenous uncertainty in the income of the primary household earner may be small beer compared to the variations in household income generated by endogenous

\footnotetext{
1 See Deaton (1992), Browning and Lusardi (1996), Browning and Crossley (2001) and Carroll (2001).

2 See for example Carroll (1992), (1994), (1997) and Gourinchas and Parker (2002).

3 See for example Deaton (1992).

4 See for example Attanasio and Browning (1995), Blundell et al. (1994), and Browning and Ejrnaes (2002).

5 Interestingly enough though, Friedman (1957), in defining his Permanent Income Hypothesis, is careful to refer to the " earners" in his "consumer unit" in the plural. This is perhaps because he does not derive his hypothesis from an explicit model of the utility maximizing household. Ando and Modigliani (1963), on the other hand, in the formulation of their Life Cycle Hypothesis, do so, and so treat the household as a single individual, which tradition has been followed in the literature ever since.
} 
choices of secondary earner labor supply. This leads to an approach which integrates life cycle choices of market and non-market time allocations and consumptions. ${ }^{6}$

In adopting this approach we incorporate elements of both demographics and capital market imperfections. Decisions on female labor supply are closely related to the presence of children and the choice of sources of supply of child care. Moreover, it seems possible to explain the data on life cycle consumption only by assuming some kind of capital market imperfection, though our data set, which gives detailed information for each household on purpose, source, amount and cost of borrowing, does not support the extreme assumption of no borrowing. Also, we certainly would not rule out the possibility that some saving could be precautionary in nature, but do not believe, from our inspection of the data, that this can be anything like a complete explanation of household consumption behavior over the life cycle.

An important feature of our modelling approach is the characterization of the life cycle not in terms of calendar years, but rather in terms of the phases through which a typical family goes over its lifetime. ${ }^{7}$ By organising the data in this way we are trying to bring out more clearly than in the existing literature the effects of children on the time allocation and labor supply decisions of the household, and, through that, on its income stream and saving decisions. Thus we argue that the time paths of saving and consumption of market goods reflect the movements in household income that are determined by changes in female labor supply over time, which in turn are determined by the process of substitution between market and household work associated with bringing up children. ${ }^{8}$

The high across-household variation in female labor supply and the corresponding variation in gross household income do not lead to a similar variation in acrosshousehold market consumption expenditure. This is partly because government taxation and family payment policies redistribute heavily from two-earner to singleearner households, so that incomes net of taxes and benefits are more equal, and partly because saving behavior depends very closely on female labor supply. For example, households with no significant female labor supply do virtually no saving once they have children, other than that involved in house purchase and superannuation schemes, and at the same time they borrow more heavily in the short term to maintain consumption. Controlling for primary earner income, households with high female labor supply invest more in housing and borrow less

\footnotetext{
6 The paper by Attanasio, Low and Sanchez-Marcos (2003) adopts an approach similar in spirit to this paper, but quite different in detail. It uses a life cycle model with endogenous female labor force participation, consumption and saving decisions to explain the changes in female participation across three age cohorts in the US.

7 See Heathcote et al. (2008) for a similar approach in the context of household labor supplies.

8 This bears a superficial resemblance to the model of Baxter and Jermann (1999). They explain the tendency for consumption of market goods to track income by arguing that as the wage rate rises over the life cycle, goods produced in the household (of which the most important is surely child care) become more expensive, and therefore substitution toward market goods takes place. In a sense they are spelling out a source of the non-separability between consumption (of market goods) and household non-labor time that was the basis for Heckman's (1974) contribution. However, the problem with this theory is that the domestic production is carried out predominantly by the female, whose wage tends not to rise over the life cycle due to withdrawal from the workforce.
} 
short term to finance consumption. Thus there is a high propensity to save out of second earner income. ${ }^{9}$

The heterogeneity in female labor supply may not be associated with similar differences in household welfare levels. The effective tax system that households at low to average income levels face defines a piecewise linear budget constraint in the space of gross and net income, with an effective marginal tax rate that falls with income over this range. ${ }^{10}$ It is then easy to show that two households may be in equilibrium very far apart in their female labor supply decisions but close together in their achieved welfare level. A small difference in household characteristics can be transformed into a large difference in female labor supply by a piecewise linear tax system that defines a non-convex budget constraint. ${ }^{11}$

\section{A family life cycle model}

We divide the life cycle into four periods, assumed of equal length for simplicity. ${ }^{12}$ In every period except the last a couple allocates its time between market work, household production and leisure. Period 1 is the pre-children phase, in period 2 children are present, in period 3 they have left the household, and in period 4 the couple has retired, and so the only uses of time are household work and leisure. We analyze first the within-period choices of expenditure and time allocations, and then the intertemporal allocation of expenditures.

\subsection{Period 1}

The individuals $f$ and $m$ jointly choose consumptions of the market and household goods $x_{i 1}, y_{i 1}$ and leisure $z_{i 1}, i=f, m$, to maximize a household welfare function (HWF)

$$
H_{1}\left[u_{f}\left(x_{f 1}, y_{f 1}, z_{f 1}\right), u_{m}\left(x_{m 1}, y_{m 1}, z_{m 1}\right)\right]
$$

subject to the following constraints. First, household production is given by

$$
\sum_{i=f, m} y_{i 1}=y_{1}=h\left(t_{f 1}, t_{m 1} ; \kappa\right)
$$

with $h($.$) a concave, linear homogeneous production function, \kappa$ an exogenous productivity indicator that varies across households, and $t_{i 1}$ are time inputs. The budget $^{13}$ and time constraints with $l_{i 1}$ denoting labor supplies are

\footnotetext{
9 A number of studies that adopt the single-person household model, either implicitly or explicitly, report a fall in the saving rate with an increase in female labor market participation. See, for example, Attanasio and Banks (1998). However, the relevant rate is that with respect to the second income, which we find to be strongly positive. In this study we support these arguments by drawing on Australian data, but other work we have done (see in particular Apps and Rees, 2009) shows that similar conclusions can be drawn for the UK and US.

10 This is true not only in Australia but also in the US and UK.

11 For further discussion of the theory and empirical observations underlying this remark see Apps and Rees (2009), Ch 6, and Apps et al. (2009).

12 In the empirical treatment below we refine this substantially, increasing the number of phases to six and allowing them to have variable length.

13 Non wage income $\mu$ can include fixed pension or superannuation contributions and so may be negative.
} 


$$
\begin{gathered}
\sum_{i=f, m} x_{i 1}=\sum_{i=f, m} w_{i 1} l_{i 1}+\mu_{1} \\
t_{i 1}+l_{i 1}+z_{i 1}=1 \quad i=f, m
\end{gathered}
$$

We can find the implicit price of the household good, $p_{1}$, as the marginal (= average) cost of its production, $\gamma\left(w_{f 1}, w_{m 1} ; \kappa\right)$, and collapse the three constraints into the single full income constraint

$$
\sum_{i=f, m}\left(x_{i 1}+p_{1} y_{i 1}+w_{i 1} z_{i 1}\right)=X_{1}
$$

In a single period model, the income on the right hand side of this constraint would be given by $\sum_{i=f, m} w_{i 1}+\mu_{1}$, which we call full income, available for consumption of all goods, including the household good and leisure. However, we know that by use of the capital market, the value of full consumption, the left hand side of (5), can deviate from full income in that period, and so the right hand side of (5), $X_{1}$, which we call full expenditure, is yet to be determined.

Solving for the optimal allocation, values of consumptions $x_{i 1}^{*}, y_{i 1}^{*}, z_{i 1}^{*}$, and time allocations $l_{i 1}^{*}, t_{i 1}^{*}$ and inserting the former into the household welfare function gives the period 1 value function $V_{1}\left(p_{1}, w_{f 1}, w_{m 1}, X_{1}\right)$. Life cycle considerations have their effect on period 1 decisions via the choice of $X_{1}$. Given this, the within-period allocation is determined by wage rates and the price of the household good.

\subsection{Period 2}

We model children by including them as individuals with their own utility functions, which appear in the HWF. Without real loss of generality we can assume just one child with the utility function $u_{k}\left(x_{k 2}, y_{k 2}, c_{k}\right)$, where $c_{k}$ is child care, produced by using parental time inputs $t_{i k}$ and a bought in market child care input $b$, with production function, also concave and linear homogeneous, given by $c_{k}\left(t_{f k}, t_{m k}, b\right)$. As before, we can define prices for the household good, and child care, given by $p_{2}=\gamma\left(w_{21}, w_{m 2} ; \kappa\right)$ and $q=\gamma_{c}\left(w_{f 2}, w_{m 2}, p_{b}\right)$, with $\gamma\left(\right.$.) and $\gamma_{c}($.) the respective unit cost functions and $p_{b}$ the price of the bought in child care input. The HWF now becomes

$$
H_{2}\left[u_{f}\left(x_{f 2}, y_{f 2}, z_{f 2}\right), u_{m}\left(x_{m 2}, y_{m 2}, z_{m 2}\right), u_{k}\left(x_{k 2}, y_{k 2}, c_{k}\right)\right]
$$

Given the parental time constraints on the four possible uses of time

$$
t_{i 2}+t_{i k}+l_{i 2}+z_{i 2}=1 \quad i=f, m
$$

the full expenditure budget constraint is

$$
\sum_{i=f, m, k}\left(x_{i 2}+p_{2} y_{i 2}\right)+\sum_{i=f, m} w_{i 2} z_{i 2}+q c_{k}=X_{2}
$$

We assume here that children supply neither domestic nor market labor. We solve for the demands for market and domestic goods and child care, and for the parental time allocations, to derive the value function for this period, $V_{2}\left(p_{2}, w_{f 2}, w_{m 2}, q, X_{2}\right)$. 
The effect of the presence of children in the household is to add to the demand for market and domestic consumption goods and to create demand for a new good, child care. All these demands will now depend inter alia on the price of child care which, in turn, except at a corner solution in which only parental time is used, will depend on the price of market child care as well as parental wage rates. ${ }^{14}$ This model therefore suggests that across-household variations in consumptions, labor supplies and the mix of market and parental child care would be explained by variation in wage rates, the price of market child care, and productivities in producing domestic goods and child care.

\subsection{Period 3}

On the assumption that when the children leave home, they place no further demands on parental time and income, ${ }^{15}$ the period three problem is identical to that in period 1 , and in the same way yields the value function $V_{3}\left(p_{3}, w_{f 3}, w_{m 3}, X_{3}\right)$.

\subsection{Period 4}

Since the individuals have retired, $l_{i 4}=0$ by definition, and so the model is as in period 3 except that the budget and time constraints are

$$
\begin{gathered}
\sum_{i=f, m} x_{i 4}=X_{4} \\
t_{i 4}+z_{i 4}=1 \quad i=f, m
\end{gathered}
$$

The household's nonwage income in this period, $\mu_{4}$, consists entirely of transfer payments from pension or superannuation schemes (but not, of course, income from the returns to past saving on the capital market). The household maximizes its HWF

$$
H_{4}\left[u_{f}\left(x_{f 4}, y_{f 4}, z_{f 4}\right), u_{m}\left(x_{m 4}, y_{m 4}, z_{m 4}\right)\right]
$$

subject to the above three constraints together with the production function constraint. We derive the value function $V_{4}\left(X_{4}\right)$ as before. Note that no wage rates enter into this value function. All prices and wage rates in this retirement period are implicit or shadow prices, determined endogenously at the household optimum by the values of the Lagrange multipliers associated with the various constraints.

Note that now all non leisure time can be devoted to household production, which could be rather cheap at the margin. Thus it would not be surprising to see a major substitution of household production for market goods, and this could well be the explanation of the "retirement income puzzle" discussed by Banks et al (1998). ${ }^{16}$

\footnotetext{
${ }^{14}$ Where the optimal time allocation implies that one partner reduces market labor supply to zero, the corresponding market wage rate gives only a lower bound on the opportunity cost of that individual's time.

15 The relaxation of this assumption would be an important area for future work. For a study of the effects of parent's and children's income on the decision of children to leave home, see le Blanc and Wolff (2006).

16 This suggestion is supported in a detailed study by Aguiar and Hurst (2005).
} 
Given the standard assumption of intertemporal separability of utility-in this case household welfare-we can now analyse the determination of the time stream of full expenditures, $X_{1}, \ldots, X_{4}$. This obviously will depend upon what we assume about the capital market. We consider two possibilities.

\subsection{Case 1: a perfect capital market}

Assume the household members agree on the intertemporal felicity discount factor $\rho$, and that the market discount factor is $\delta$. Then the household's problem is simply

$$
\max _{X_{t}} \sum_{t=1}^{4} \rho^{t-1} V_{t}\left(X_{t}\right) \quad \text { s.t. } \sum_{t=1}^{4} \delta^{t-1} X_{t} \leq \sum_{t=1}^{3} \delta^{t-1}\left(\sum_{i=f, m} w_{i t}+\mu_{t}\right)+\delta^{3} \mu_{4} \equiv W
$$

where $\mu_{4}$ includes all non-capital market income such as state pensions, superannuation payments and so on, and $W$ denotes wealth.

The full consumption stream can be decoupled from the full income stream and is chosen to satisfy the condition that discounted marginal utility of full expenditure on consumption of market and household goods and leisure, and on child care in period 2 , is equalized across periods, i.e. we have

$$
\left(\frac{\rho}{\delta}\right)^{t-1} V_{t}^{\prime}\left(X_{t}^{*}\right)=\lambda^{*} \quad t=1, \ldots, 4
$$

with $\lambda^{*}$ the marginal utility of household wealth.

\subsection{Case 2: an imperfect capital market}

The household can save at a given (low) interest rate $r_{s}$, or borrow at an interest rate $r_{b t}=r\left(b_{t}\right)$ in any period $t=1, \ldots, 4$, where the interest rate is an increasing function of borrowing $b_{t}$. A kink in the intertemporal budget constraint is created by the assumption that $r(0)>r_{s}$. A household may be in equilibrium by lending at rate $r_{s}$, borrowing at a marginal cost of $m_{t}^{*}\left(b_{t}^{*}\right) \equiv 1+r\left(b_{t}^{*}\right)+r^{\prime}\left(b_{t}^{*}\right) b_{t}^{*}$, or neither. A large difference $r(0)-r_{s}$ could lead to many households being in this latter position.

Thus, the household solves the problem

$$
\begin{gathered}
\max \sum_{t=1}^{4} \rho^{t-1} V_{t}\left(X_{t}\right) \quad \text { s.t. } \\
X_{t} \leq \sum_{i=f, m} w_{i t}+\mu_{t}-s_{t}+b_{t}+\left(1+r_{s}\right) s_{t-1}-\left(1+r_{b, t-1}\right) b_{t-1} \\
b_{t} \geq 0, \quad s_{t} \geq 0 \quad t=1, \ldots, 4, \quad l_{i 4}=s_{0}=b_{0}=s_{4}=b_{4}=0
\end{gathered}
$$

The key difference between the perfect and imperfect capital market models lies in the impact of changes in household per capita income in a given period on consumption in that period. In the case of a perfect capital market that impact is diffused over the entire lifetime. In an imperfect capital market, a change in income in a given period can have a large effect on optimal consumption in that period, the more so, the greater the slope of the borrowing rate function. 


\section{Data and life cycle phases}

We combine time use and household income and expenditure data from two surveys: ${ }^{17}$ the Australian bureau of statistics (ABS) 2005-2006 time use survey (TUS) and the ABS 2003-2004 household expenditure survey (HES). The TUS provides detailed information collected by diary, for two diary days, on the allocation of time to labor market activities and to nine non-market activity episode classifications: personal care, education, domestic activities, child care, purchasing goods and services, voluntary work and care, social and community interaction, active recreation and passive leisure. We aggregate non-market activities into three categories: domestic work, child care and leisure. We refer to the total time allocated to domestic work and child care as household production. Leisure is the sum of time allocations to all other activities. The HES contains data collected by interview on household consumption expenditure, labor supply, earnings, non-labor incomes, as well as estimates of government indirect taxes and benefits, and detailed data on direct taxes and benefits, house price, housing debt, mortgage payments, and contributions to mandatory retirement saving and to life insurance.

We select couples from each survey excluding only those records reporting negative incomes in the HES. This gives samples containing 2,085 records from the TUS and 4,064 records from the HES. Using regression models estimated on the TUS data, we merge information on time use with income and consumption data for each record in the HES sample.

To ensure that the time constraint is satisfied, we predict time use ratios. We estimate as functions of observed variables the ratios of leisure to non-market time (leisure plus household production), $\tau_{z_{i}}=z_{i} /\left(t_{i}+t_{i k}+z_{i}\right)$ and child care to household production time, $\tau_{t_{i k}}=t_{i k} /\left(t_{i}+t_{i k}\right), i=1,2$, where $t_{i}$ is domestic work, $t_{i k}$ is child care time and $z_{i}$ is leisure. The regressors include dummy variables for age of youngest child, interaction variables that capture the effect of additional children at each age of youngest child, and the characteristics of the adults, including age and dummy variables for education and employment status. Nonmarket time is computed from the time constraint as $T-l_{i}$, where $T$ is total time available. The predicted value for $\tau_{z_{i}}$ is used to compute each individual's leisure time as $\left(T-l_{i}\right) *\left(\tau_{z_{i}}+u_{i}\right)$, where $u_{i}$ is a randomly selected element from the residuals of the regression estimated on the TUS data. Household production time is computed from the time constraint as $T-l_{i}-z_{i}$. Using the result and the predicted value for $\tau_{z_{i}}$, the allocation of time to child care is computed by the same procedure.

The sample of couples is partitioned into six broad life cycle phases: Phase 1, pre-children; Phase 2, pre-school age children; Phase 3, children predominantly of primary school age; Phase 4, children in later years of high school or in tertiary education; Phase 5, pre-retirement and post-children; Phase 6, retirement age.

Phase 1 couples are selected on the criteria that there are no dependent children present in the household and the female partner is aged from 20 to 41 years. In phase 2 there is at least one child under 5 present. Phase 3 families have at least one child under 10 and in phase 4 there are only older dependent children present. Phase

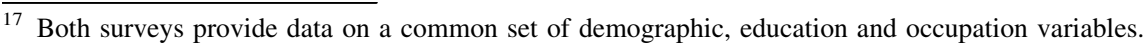


5 includes couples in which the male partner is under 60 years, the female partner is at least 42 years, and there are no dependent children present. In phase 6 the male partner is aged from 60 to 79 years and there are no dependent children present.

We now show that organising the data in this way leads to a very different picture of income, consumption and saving in the earlier years of the life cycle, a picture that is as familiar to everyday experience as it is foreign to the standard life cycle literature.

\section{Life cycle profiles}

\subsection{Family time use}

Table 1 lists data means for female and male hours of market work, domestic work and child care across the six life cycle phases. Figure 1a shows that in phase 1 both partners work full time in the vast majority of households and so partners work similar hours. In phase 2 female hours drop to well below half their pre-child level, and remain much lower for the remainder of the life cycle. There is almost no change in male hours until phase 5 . The fall at this point is obviously significant, but in no way matches the fall in female labor supply from phase 2 and thereafter.

Figure 1b shows graphically that the fall in female labor supply is more than matched by a rise in the allocation of time to household production, with most of the additional time in the early child rearing phases allocated to child care. This suggests that, with the arrival of children, household production and female labor supply become close substitutes. The most dramatic substitution occurs in phase 2 .

Figure 1c shows that leisure falls quite dramatically with the arrival of children, especially for the female, and then steadily rises over subsequent phases to give a U-shaped profile for each partner. Married women tend to reduce both market work and leisure to work longer at home, whereas married men tend to reduce only their leisure hours, with the substitution being almost entirely towards child care.

Studies that organise the data by age of head diffuse the dramatic fall in female labor supply in phase 2 by combining couples in phase 1 with those in phases 2 and 3 in the younger "age of head" categories. The result is a female profile that tends to

Table 1 Market, domestic, child care and leisure hours

\begin{tabular}{|c|c|c|c|c|c|c|c|c|}
\hline \multirow[t]{2}{*}{ Life cycle phase } & \multicolumn{3}{|c|}{ Female hours $\mathrm{pa}^{\mathrm{a}}$} & \multicolumn{3}{|c|}{ Male hours $\mathrm{pa}^{\mathrm{a}}$} & \multirow{2}{*}{$\begin{array}{l}\text { \# dep. } \\
\text { children }\end{array}$} & \multirow{2}{*}{$\begin{array}{l}\text { Cell } \\
\text { size }\end{array}$} \\
\hline & Market & Domestic & Child care & Market & Domestic & Child care & & \\
\hline 1 & 1772 & 947 & - & 2120 & 767 & - & & 433 \\
\hline 2 & 764 & 1541 & 2527 & 2105 & 813 & 1013 & 1.91 & 724 \\
\hline 3 & 952 & 1811 & 1287 & 2067 & 871 & 670 & 2.29 & 586 \\
\hline 4 & 1244 & 1887 & 420 & 2001 & 850 & 249 & 1.62 & 556 \\
\hline 5 & 1048 & 1663 & - & 1704 & 925 & - & & 811 \\
\hline 6 & 265 & 1721 & - & 461 & 1258 & - & & 948 \\
\hline
\end{tabular}

a Weighted data means 

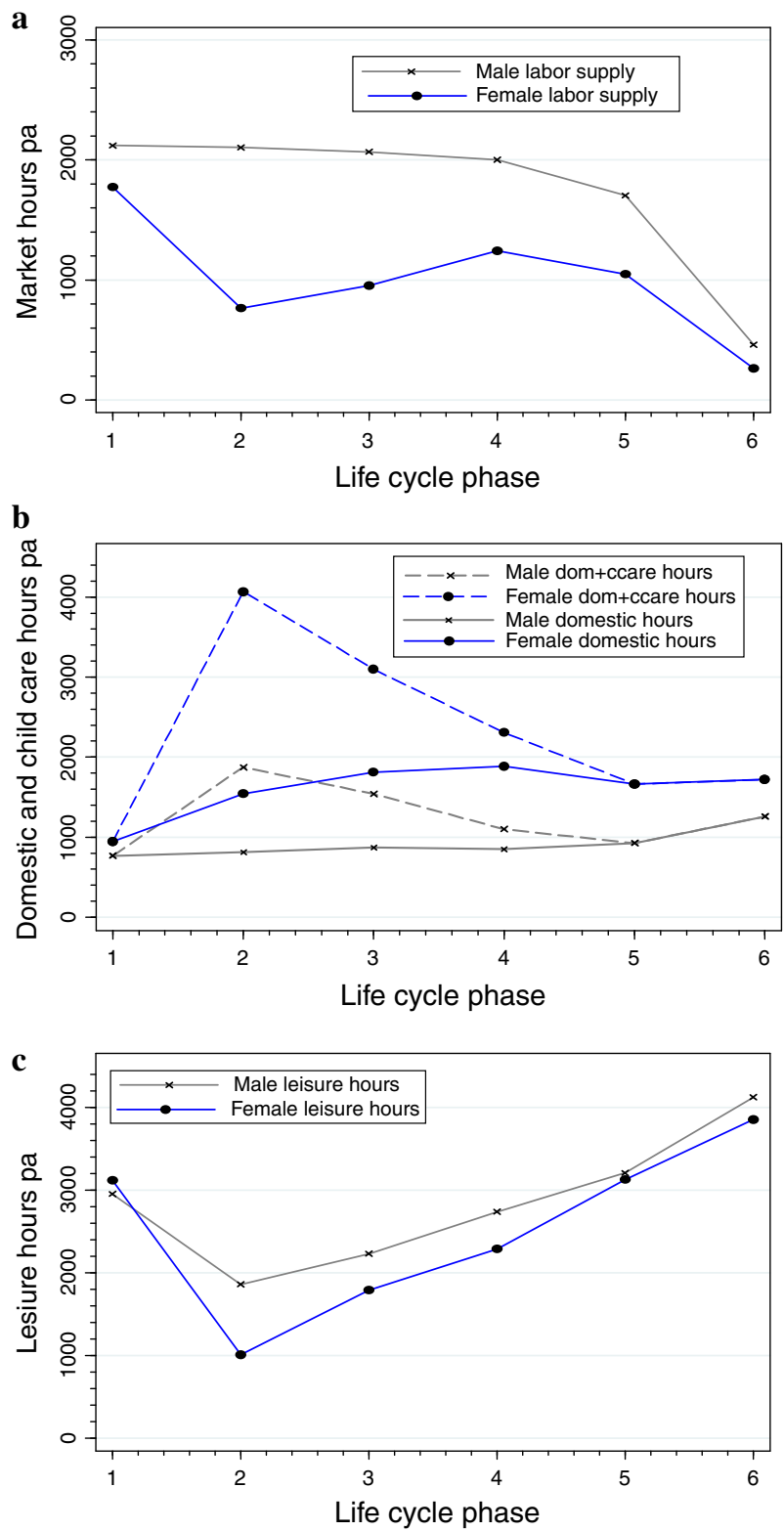

Fig. 1 a Market hours. b Domestic work and child care hours. c Leisure hours

replicate the male profile at a lower level of hours. This may in part account for the acceptance of the single-person model as a harmless simplification. However, the model can lead to a serious misinterpretation of the data. For example, Erosa and Gervais (2002) use a life cycle model based on a within-period single-person workleisure choice decision, and then take as given that "consumption and leisure 
Table 2 Time allocations by household type

\begin{tabular}{|c|c|c|c|c|c|c|c|}
\hline \multirow[t]{2}{*}{ Life cycle phase } & \multicolumn{3}{|c|}{ Female hours $\mathrm{pa}^{\mathrm{a}}$} & \multicolumn{3}{|c|}{ Male hours $\mathrm{pa}^{\mathrm{a}}$} & \multirow[t]{2}{*}{ \# dep. children } \\
\hline & Market & Domestic & Child care & Market & Domestic & Child care & \\
\hline \multicolumn{8}{|c|}{ Household type $\mathrm{H}_{1}$} \\
\hline 2 & 26 & 1832 & 2851 & 2055 & 798 & 990 & 2.07 \\
\hline 3 & 265 & 2069 & 1494 & 2029 & 867 & 672 & 2.38 \\
\hline 4 & 467 & 2203 & 506 & 1886 & 889 & 258 & 1.69 \\
\hline 5 & 237 & 1980 & - & 1446 & 29 & - & - \\
\hline \multicolumn{8}{|c|}{ Household type $\mathrm{H}_{2}$} \\
\hline 2 & 1502 & 1250 & 2203 & 2155 & 828 & 1036 & 1.75 \\
\hline 3 & 1639 & 1553 & 1080 & 2105 & 875 & 668 & 2.20 \\
\hline 4 & 2021 & 1571 & 334 & 2116 & 811 & 240 & 1.54 \\
\hline 5 & 1859 & 1346 & - & 1962 & 921 & - & - \\
\hline
\end{tabular}

a Weighted data means

[measured as non-market time] generally move together over time". The data in fact show that the rise in female non-market time in phase 2 strongly dominates any increase in both partners' non-market time allocations in the pre-retirement phase.

\subsection{Heterogeneity and time use}

To indicate the degree of heterogeneity in female time use, concealed in the preceding profiles of the time use decisions of the "average" household, we partition households in each of phases $2-5$ into two "types": ${ }^{18}$

Type H1: the female partner is employed below median hours, and

Type H2: the female partner is employed at or above median hours.

Table 2 presents data means for time allocations for market work, domestic work and child care for each household type within each phase. On average, mothers who work fewer hours in the market work longer hours at home, again with most of the additional time in phase 2 spent on child care. Overall, there is only a small gap between the total hours of work (market plus household) of each type. While the leisure profiles of partners in both household types remain strongly U-shaped, the choice by the female partner to work longer hours in the market carries with it less leisure throughout the entire life cycle. Note that, on average, the two household types have close to the same number of children. We also find that they have close to the same wage rates during the child rearing years. ${ }^{19}$

\footnotetext{
18 Ideally, we would like to construct the life cycle profiles of the two types using panel data. Since we have access to cross section data only, we are implicity assuming that household time use decisions do not oscillate over the life cycle, that is, that panel data would support the hypothesis of "persistence", as indicated in Shaw (1994).

19 This finding is based on predicted wage rates with regressors including age, education and occupation. The female wage is estimated on data for a sample of in-work records, applying the Heckman correction for selectivity bias.
} 
Table 3 Household income, female earnings, taxes and benefits, \$pa

\begin{tabular}{llrrrrr}
\hline $\begin{array}{l}\text { Life cycle } \\
\text { phase }\end{array}$ & \begin{tabular}{l} 
H'hold private $_{\text {income }^{\mathrm{b}}}$ \\
\hline 1
\end{tabular} & $\begin{array}{l}\text { Female } \\
\text { earnings }^{\mathrm{b}}\end{array}$ & $\begin{array}{l}\text { Direct } \\
\text { taxes }^{\mathrm{a}}\end{array}$ & $\begin{array}{l}\text { Direct } \\
\text { benefits }^{\mathrm{a}}\end{array}$ & $\begin{array}{l}\text { Indirect } \\
\text { benefits }^{\mathrm{a}}\end{array}$ & $\begin{array}{c}\text { All taxes- } \\
\text { all benefits }^{\mathrm{a}}\end{array}$ \\
2 & 79612 & 33800 & 20196 & 685 & 5140 & 24233 \\
3 & 57928 & 0 & 14764 & 6009 & 15232 & 2593 \\
4 & 68900 & 15392 & 17977 & 6400 & 24664 & -3725 \\
5 & 71812 & 21268 & 18967 & 4223 & 21583 & 4798 \\
6 & 59176 & 16061 & 15309 & 4597 & 7560 & 13196 \\
\hline
\end{tabular}

${ }^{\mathrm{a}}$ Weighted data means. ${ }^{\mathrm{b}}$ Medians

\subsection{Taxes and benefits}

The characterization of the life cycle in terms of "family" phases rather than on "age of head" has great policy relevance because many OECD countries, for example the US, UK and Australia, provide cash benefits based on the presence and age of children. In addition, the payments are often withdrawn on family income, and therefore vary with female labor supply decisions. This reinforces the tendency for taxes to track female earnings in the early and middle phases of the life cycle, as Table 3 shows. $^{20}$

Household private income strongly tracks female labor supply and earnings during the working age phases. ${ }^{21}$ Overall, taxes and benefits redistribute income from households without children to those with children during the working age years and have the effect of moderating significantly the fall in household private income due to a fall in female earnings, especially in the school age years.

\subsection{Net income, market consumption and saving}

Figure 2 presents life cycle profiles of median household net income, ${ }^{22}$ market consumption and saving. When the data are organized according to a family life cycle rather than by age of head, we do not obtain the usual single "hump" shaped profile of net income, ${ }^{23}$ despite the moderating effect of direct taxes and benefits. Instead there is first a fall in net income as the household moves from phase 1 to 2 , and a smaller fall in market consumption expenditure. Phase 2 is followed by a "hump"in both net income and consumption. Median saving, calculated as the difference between net income and consumption expenditure, is at a life cycle peak of $\$ 8,164$ in phase 1 (see Table 4 below). This is followed by a dramatic fall to

\footnotetext{
${ }^{20}$ For details of the calculation of non-cash benefits, see ABS (2001).

21 Both male earnings and the male wage (based on predicted values) rise across the child rearing phases. The fall in household private income in phase 2 therefore cannot be attributed to a fall in the male wage associated with any tendency for higher income earners to have their first child at a later age.

22 Net income is the sum of labor and non-labor incomes, net of taxes and government cash transfers.

23 As for example in Attanasio and Browning (1995), Blundell et al. (1994), Deaton (1992) and Gourinchas and Parker (2002).
} 


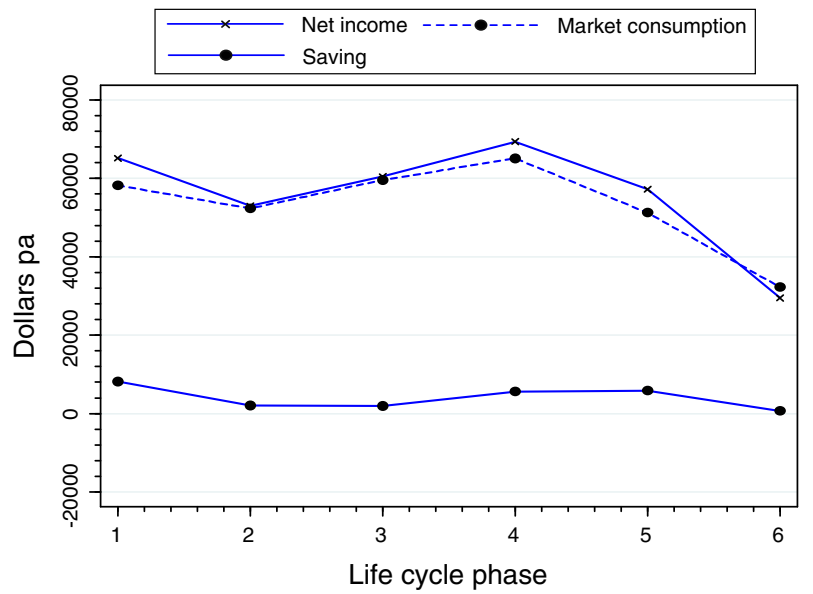

Fig. 2 Median net income, consumption and saving

Table 4 Long term vs. short term saving, \$pa

\begin{tabular}{llclcll}
\hline $\begin{array}{l}\text { Life cycle } \\
\text { phase }\end{array}$ & $\begin{array}{l}\text { Long term } \\
\text { saving }^{\mathrm{b}}\end{array}$ & $\begin{array}{l}\text { Short term } \\
\text { saving }^{\mathrm{b}}\end{array}$ & $\begin{array}{l}\text { Super }+ \text { life } \\
\text { insurance }^{\mathrm{a}}\end{array}$ & $\begin{array}{l}\text { Mortgage } \\
\text { repayments }^{\mathrm{a}}\end{array}$ & $\begin{array}{l}\% \text { home } \\
\text { owners }\end{array}$ & $\begin{array}{l}\text { Debt/house } \\
\text { price ratio \% }\end{array}$ \\
\hline 1 & 8164 & -2132 & 969 & 11066 & 61.8 & 49.4 \\
2 & 2028 & -3796 & 1263 & 9613 & 69.4 & 35.0 \\
3 & 1898 & -5980 & 1767 & 8098 & 77.9 & 23.0 \\
4 & 5564 & -1066 & 1669 & 7156 & 86.4 & 18.1 \\
5 & 5772 & 2288 & 2961 & 4585 & 84.2 & 9.8 \\
6 & 676 & 208 & 1028 & 505 & 90.5 & 1.1 \\
\hline
\end{tabular}

${ }^{\mathrm{a}}$ Weighted data means. ${ }^{\mathrm{b}}$ Medians

$\$ 1,898$ across phases 2 and 3. Thereafter saving rises until the retirement phase but does not return to its phase 1 level. These results indicate that saving, as well as household income, strongly tracks female labor supply.

The calculation of saving as the difference between net income and consumption expenditure gives, in effect, the household's long term saving, but this is not the full picture of what is going on. The data indicate that many households are, in fact, borrowing short term to meet various forms of long term contractual saving, such as mortgage payments on housing loans and contributions to a mandatory system of superannuation. Table 4 lists the median short term saving in each phase, obtained by subtracting total spending from net income. While median long term saving is positive in each phase, short term saving is negative in phases 1-4: the median household in these phases is in the position of having to borrow short term to finance long term saving.

Table 4 also lists average contributions to superannuation and life insurance, average mortgage payments, the percentage of households who are home owners or purchasers, and the average debt to house price ratio. The strong incentive to save 
Table 5 Incomes, taxes and saving by household type, \$pa

\begin{tabular}{|c|c|c|c|c|c|c|c|}
\hline $\begin{array}{l}\text { Life cycle } \\
\text { phase }\end{array}$ & $\begin{array}{l}\text { Male } \\
\text { income }^{a}\end{array}$ & $\begin{array}{l}\text { Female } \\
\text { income }^{\mathrm{a}}\end{array}$ & $\begin{array}{l}\text { Direct } \\
\text { taxes }^{\mathrm{a}}\end{array}$ & $\begin{array}{l}\text { Direct } \\
\text { benefits }^{a}\end{array}$ & $\begin{array}{l}\text { All taxes- } \\
\text { benefits }^{\mathrm{a}}\end{array}$ & $\begin{array}{l}\text { Long term } \\
\text { saving }^{\mathrm{b}}\end{array}$ & $\begin{array}{l}\text { Short term } \\
\text { saving }^{\mathrm{b}}\end{array}$ \\
\hline \multicolumn{8}{|c|}{ Household type H1 } \\
\hline 2 & 47264 & 1986 & 10944 & 9041 & -5740 & -1716 & -6708 \\
\hline 3 & 54499 & 6033 & 16035 & 9230 & -9782 & -910 & -8658 \\
\hline 4 & 51984 & 11982 & 17309 & 6764 & -1691 & 2730 & -3120 \\
\hline 5 & 34175 & 7347 & 10495 & 6951 & 4180 & 2028 & -130 \\
\hline \multicolumn{8}{|c|}{ Household type $\mathrm{H} 2$} \\
\hline 2 & 49736 & 32967 & 18584 & 2977 & 10925 & 6240 & -1560 \\
\hline 3 & 52055 & 36113 & 19919 & 3569 & 2332 & 5508 & -2600 \\
\hline 4 & 49426 & 38606 & 20624 & 1682 & 11211 & 8866 & -338 \\
\hline 5 & 43307 & 36051 & 20123 & 2207 & 22213 & 13156 & 5356 \\
\hline
\end{tabular}

${ }^{\mathrm{a}}$ Weighted data means. ${ }^{\mathrm{b}}$ Medians

for house purchase is reflected in the decline in the housing debt to house price ratio from 49.4 per cent in phase 1 to 1.1 per cent in phase 6 , a decline that follows a rise in the percentage of home owners, from 61.8 per cent in phase 1 to 90.5 per cent in phase 6. It is straightforward to show that the user cost of owner occupied housing, obtained by discounting payments of capital and the initial equity at the time of purchase, becomes negative over time, due primarily to capital gains in an imperfect capital market and also to low transactions costs for home ownership relative to private rental. ${ }^{24}$ For this reason we exclude mortgage payments from consumption spending in the calibration of the capital market models in Sect. 5. Essentially, we treat mortgage payments as a tax that has to be paid in the early phases of the life cycle to obtain housing at a near zero implicit rent over the life cycle.

\subsection{Heterogeneity, taxes and saving}

The preceding life cycle profiles of incomes, taxes and saving conceal a high degree of within-phase heterogeneity and the way in which these variables track withinphase female labor supply. This is evident from the data means and medians for each household type reported in Table 5.

Both types have close to the same average male incomes in the child rearing phases. However, with much lower female earnings in phase 2 the H1 household attracts a much lower level of taxation under the Australian personal income tax. ${ }^{25}$ The result is driven by the fact that the $\mathrm{H} 1$ household avoids tax by substituting untaxed household production for taxed market work, and receives far more in

\footnotetext{
${ }^{24}$ The data suggest that, under these conditions, home ownership is analogous to an annuity with a high rate of return, especially if households minimize transactions costs by rarely moving house over the life cycle. Preferential tax treatment is also a contributing factor but cannot alone explain the user cost differential between owning and renting over time if one assumes, implausibly, a perfect capital market.

25 The Australian personal income tax applies a progressive rate scale to individual incomes. This means that the second earner on a lower income faces a lower marginal tax rate. This contrasts with a system of joint taxation, which imposes a higher rate on the second income.
} 
direct benefits. Indirect benefits are more closely matching because education benefits are based primarily on demographics, and both household types have close to the same number of dependent children in each phase. Overall, the $\mathrm{H} 2$ household in phase 2 loses around $\$ 16,000$ of the income of the female partner. This reflects very high effective marginal tax rates at low and average income levels due to targeting family payments, and implies an average tax rate of around 50 per cent for many married mothers as second earners. Once the family payments are fully withdrawn, the marginal rates on both primary and second incomes fall to the rates that apply under the personal income tax. ${ }^{26}$

As noted in the introduction, under this type of family tax system, households face a piecewise linear budget constraint in the space of gross and net income, with an effective marginal tax rate that falls with income. Two households in equilibrium may therefore be very far apart in their female labor supply decisions but close together in their achieved welfare level. A small difference in household characteristics can be transformed into a large difference in female labor supply by a piecewise linear tax system that defines a non-convex budget constraint. The structure of the tax system may therefore be an important driver of female labor supply heterogeneity. Other explanations include differences in domestic productivities and the price of non-parental child care.

The final two columns of the table report median long term and short term saving. A much stronger positive association between household saving and female labor supply becomes evident when we compare the saving behavior of the two household types within phases $2-5$. Short term borrowing is strongly negatively associated with female labor supply.

The contrasting saving profiles indicate that much of the additional household income derived from female earnings is used to increase saving and to reduce the household's short term borrowing requirements. An answer to the question as to what drives female labor supply heterogeneity will therefore also offer an explanation for heterogeneity in household saving decisions at given wage rates and demographic characteristics.

\subsection{Consumption and household production}

As we have argued, to obtain a true picture of life cycle consumption it is essential to include household production. We also need to include indirect government benefits because they vary significantly across phases. In this section we present life cycle profiles of market consumption expenditure including indirect government benefits (labeled "mkt") and the household's combined market output and household production expenditure (labeled "mkt+hhp"). On the assumption of constant returns to scale of time inputs, expenditure on household production at the implicit price of output is given by the value of time, measured here by the net wage, spent on domestic work and child care. In addition, we report full consumption expenditure computed as the sum of the opportunity cost of each

\footnotetext{
${ }^{26}$ For a detailed analysis of the Australian personal income tax and family tax benefit system, and for international comparisions, see Apps and Rees (2009), Ch 6.
} 
Table 6 Adult consumption expenditures and child costs, \$pa

\begin{tabular}{lllllll}
\hline Life cycle phase & \multicolumn{3}{l}{ Adult consumption expenditures } & & \multicolumn{2}{l}{ Child costs } \\
\cline { 2 - 3 } & Full & Mkt + hhp & Mkt & & Mkt + hhp & Mkt \\
\hline 1 & 137298 & 78144 & 56507 & & \\
2 & 75390 & 57163 & 39253 & 69379 & 22797 \\
3 & 92800 & 60059 & 40715 & & 67986 & 37644 \\
4 & 117008 & 72992 & 51244 & & 46836 & 32575 \\
5 & 147111 & 88003 & 55895 & & \\
6 & 137087 & 75567 & 47710 & & \\
\hline
\end{tabular}

partner's leisure evaluated at the net wage, expenditure on market goods and implicit expenditure on household production.

We assign shares of consumption to the adults and children in the household by computing child costs based, as far as possible, on the available data. Child costs include the parental time cost of child care, private spending on market child care and education, and government indirect education and child care benefits, for which we have data. The children's shares of unassigned market and domestic goods are computed by applying an equivalence scale that sets the share of a child to 0.4 of that of an adult. ${ }^{27}$

Table 6 gives the data means for these consumption variables, with the LHS reporting the results for adult consumption expenditures and the RHS, the costs of children. ${ }^{28}$ Consumption expenditure at the level of the household is obtained by adding the cost of children to the consumption expenditure of the adults. Figure $3 \mathrm{a}$ and $b$ presents the results graphically.

The profiles exhibit a number of striking features. First, the paths of parents' consumptions are strongly U-shaped, consistent with their leisure profiles. Equally importantly, the household profiles show that children are very costly, especially in the early child rearing years due to the high parental time costs in those years. The U-shaped profiles of the adults' consumption expenditures show that parents do not use the capital market to fully smooth their consumption. The explanation for this that we suggest is that parents face higher interest rates in the early child rearing phases, together with a lack of access to high quality, affordable market child care. In addition, high effective tax rates can apply to a second income. As a result, the optimal choice for many households is, first, to reallocate the mother's time from market to household work, since she generally faces a lower wage, and secondly, for both parents, but especially the mother, to work longer hours in total, and so reduce leisure, in phase 2.

In later years, the cost of children to parents is substantially reduced by public funding of education. When the child reaches school age the public education

\footnotetext{
27 This ratio of child to adult consumption is used, for example, in Blundell et al (1994) to deflate household market consumption expenditure.

${ }^{28}$ Child costs of the order reported in the table are consistent with results for a "sharing rule"in a multiperson model estimated on time use data in Apps and Rees (2001).
} 

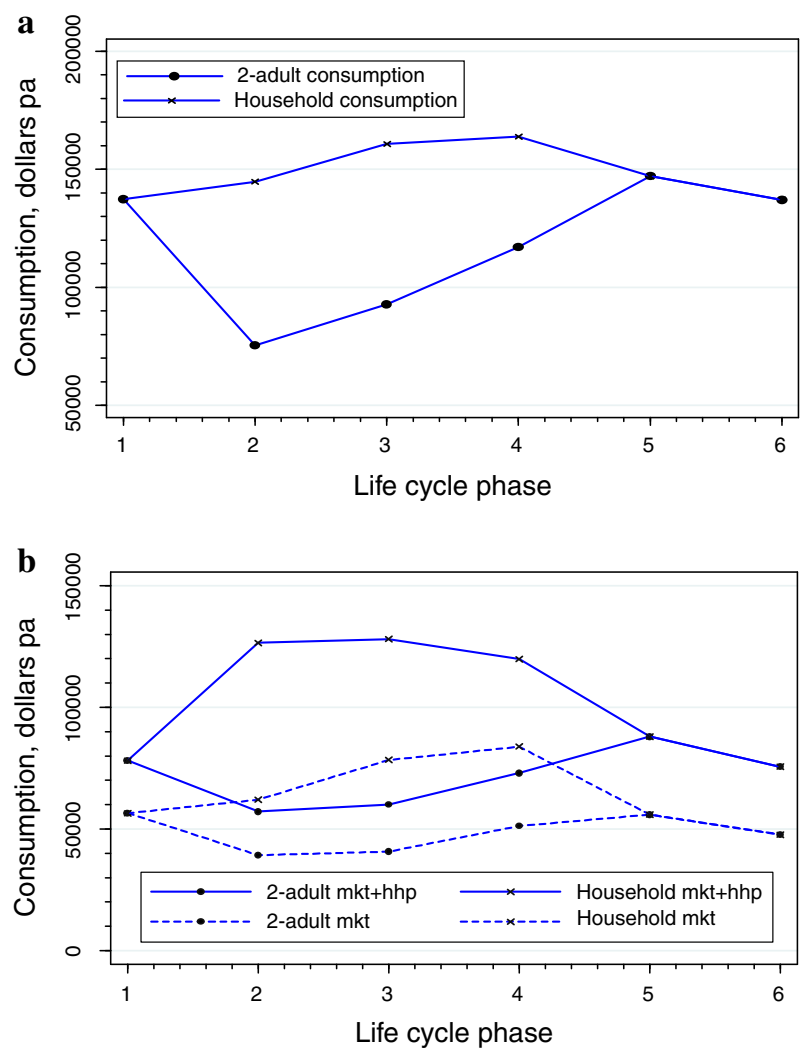

Fig. 3 a Full consumption. b Mkt + hhp and mkt consumption

system takes over many of the child-minding activities that the household itself has to undertake for preschool children. With a large component of the cost of children met by government, the female partner can expand her market labor supply, while simultaneously reducing total hours of work once the preschool phase is over.

This effect is evident in phase 3 and is accentuated in phase 4 . As we saw in Table 3 and Fig. 2, household income and market consumption expenditure peak in phase 4, with teenaged and older children living at home and female hours at their second highest level. Saving is at its second highest level in phase 5, when the children have left home. Thus, the profiles of total hours of work and of adult consumptions, are, we argue, to a significant extent an outcome of an imperfect capital market and variations in the public funding of the costs of children.

\subsection{Consumption and heterogeneity}

Table 7 lists the data means for "full", "mkt + hhp" and "mkt" consumptions of the adults in the household for records partitioned into type $\mathrm{H} 1$ and $\mathrm{H} 2$ in phases 2-5. The table also reports child costs for each household type. Figure $4 \mathrm{a}$ and $\mathrm{b}$ 
Table 7 Adult consumption and child costs by household type, \$pa

\begin{tabular}{|c|c|c|c|c|c|}
\hline \multirow[t]{2}{*}{ Life cycle phase } & \multicolumn{3}{|c|}{ Adult consumption expenditures } & \multicolumn{2}{|l|}{ Child costs } \\
\hline & Full & $\mathrm{Mkt}+\mathrm{hhp}$ & Mkt & Mkt + hhp & Mkt \\
\hline \multicolumn{6}{|c|}{ Household type H1 } \\
\hline 2 & 76755 & 58416 & 38115 & 71943 & 20617 \\
\hline 3 & 97676 & 61130 & 39114 & 70528 & 36761 \\
\hline 4 & 123554 & 74600 & 50276 & 49846 & 32013 \\
\hline 5 & 152733 & 85056 & 51284 & & \\
\hline \multicolumn{6}{|c|}{ Household type $\mathrm{H} 2$} \\
\hline 2 & 74026 & 55910 & 40392 & 66748 & 24918 \\
\hline 3 & 7925 & 58989 & 42316 & 65332 & 38523 \\
\hline 4 & 110462 & 71384 & 52212 & 43453 & 32958 \\
\hline 5 & 141489 & 90951 & 60506 & & \\
\hline
\end{tabular}

depict the results graphically using the overall data means for phases 1 and 6 , since almost all adults in phase 1 are working full time and almost all in phase 6 are retired.

The market consumption profiles of the two household types are closely matching despite the gap between their average household incomes. This reflects the significant redistribution of income from the $\mathrm{H} 2$ to the $\mathrm{H} 1$ household through the family tax system and the lower level of short term borrowing by the $\mathrm{H} 2$ household. The "mkt + hhp" consumption profiles are also closely matching but with the $\mathrm{H} 2$ profile below that of the $\mathrm{H} 1$ type across phases $2-4$ because the former allocates less time to household production. And with less leisure, the H2 household's full consumption falls further below that of the H1 household across phases 2-5.

Thus, although the second earner in the $\mathrm{H} 2$ household works much longer hours in the market than her counterpart in the $\mathrm{H} 1$ household, her extra hours contribute relatively little to raising her household's life cycle profile of market consumption. The result suggests that an important motivation for a second earner is saving for the purpose of reducing short term borrowing needed to meet mortgage payments. ${ }^{29}$

Both types of households of course are affected by the inability to use the capital market to smooth the time profile of leisure and full consumption. The tax-benefit system however, rather than correcting for this by supporting all households in the early child-rearing phases, simply brings about very large transfers from the $\mathrm{H} 2$ to the $\mathrm{H} 1$ household. The implied high marginal tax rates on working wives are clearly very questionable on efficiency grounds, while it is not a priori clear whether there are gains in equity of the income distribution. For this we would need to know exactly how variation in household productivities, and therefore in the relative price of child care, are correlated with female labor supply across households, something about which virtually nothing is known empirically. Our own judgement is that policy changes to reduce the tax burden on working married women and increase

\footnotetext{
${ }^{29}$ This is consistent with the empirical studies on the relationship between female labor supply and asset acquisition, see for example Fortin (1995).
} 

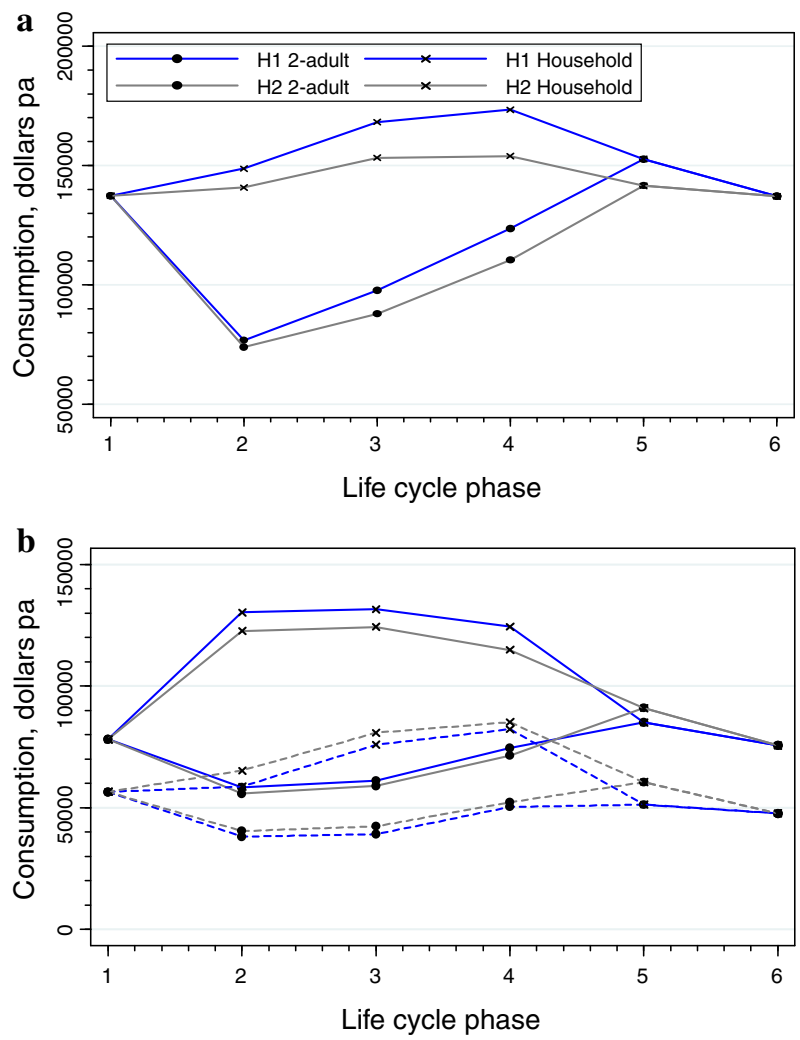

\begin{tabular}{|c|c|c|c|}
\hline$\longrightarrow$ & H1 2-adult mkt+hhp & $\longrightarrow$ & $\mathrm{H} 1$ household $\mathrm{mkt}+\mathrm{hhp}$ \\
\hline & H2 2-adult mkt+hhp & $\longrightarrow$ & $\mathrm{H} 2$ household $\mathrm{mkt}+\mathrm{hhp}$ \\
\hline---- & H1 2-adult mkt & $----x----$ & $\mathrm{H} 1$ household mkt \\
\hline---- & H2 2-adult mkt & $----x----$ & $\mathrm{H} 2$ household mkt \\
\hline
\end{tabular}

Fig. 4 a Full consumption by household type. b Mkt + hhp and mkt consumption by household type

support for child care through public investment in the sector ${ }^{30}$ would significantly improve both efficiency and equity, as well as increase fertility. Given the limitations of the data, the following section focusses on testing the hypothesis of an imperfect capital market for the average household.

\section{The capital market}

The data we have presented suggest the following picture for the solution to the household's problem presented in Eqs. $(14,15,16)$ of the life cycle model in Sect. 2. In period 1, when the couple has two incomes and no children, saving is substantial.

\footnotetext{
30 Note that the support needs to centre on the development of a public investment program in the sector. Subsidies for privatised child care cannot provide a long term solution in an imperfect capital market.
} 
This is consistent with the precautionary saving of the buffer stock model, though it is important to note that the median household even in this phase is a short-term net borrower on the capital market. The high level of saving is essentially due to house purchase and superannuation contributions, to some extent financed by short term borrowing at interest rates higher than those paid on saving in the capital market. This is not only a characteristic of Australia, but also of countries such as the US and UK with similar housing markets and tax-advantaged retirement saving programmes.

The data show that in phase 2 there is a substantial shock to saving and consumption. Not only is there an additional source of demand for consumption of market and domestic goods, but the new demand for child care has major implications for time allocation and the household's market income. ${ }^{31}$ The household has to decide on how it will meet these increased demands, especially for child care. We can think of it as choosing among different mixes of market and parental child care. One solution is for the secondary earner to drop out of the labor market altogether, another is for her to switch to part-time working, the third is for her to continue in full time employment, using a lot of bought in child care. Significant proportions of households choose each solution. The within-period model for period 2 set out in Sect. 2 suggests that the determinants of this choice are wage rates, the price of bought-in child care, and relative productivities of parental and market child care.

To this the intertemporal model adds capital market conditions, in particular the interest rate on saving and the borrowing rate in the child rearing phases, since these determine the household's ability to smooth its consumption path. In the perfect capital market model, we would predict a substantial switch to borrowing, to smooth the drop in adult consumption (including leisure) that the data show takes place in period 2. However, borrowing in period 2 remains relatively low for most households. This suggests that the imperfect capital market is likely to be a better model for predicting the data.

In this section we test this hypothesis by calibrating the perfect and imperfect capital market models for the "average" household. As noted, we focus on this issue due to the limitations of the available data. We do not have information on the relative productivities of parental and market child care or reliable data on the price of bought-in child care. ${ }^{32}$ Domestic output is missing. We therefore cannot compute prices for domestic output and child care, other than by specifying a functional form that, in effect, constructs the missing data. Data on individual consumptions of market and domestic goods are also missing. While the TUS provides information on adult leisures and parental child care and the HES contains data on parental and government spending on child care and education, these data alone do not allow the identification of individual preference parameters or the estimation of the parameters of an intra-household sharing rule. We therefore assign shares of

\footnotetext{
${ }^{31}$ An early empirical paper, Gronau (1980), also points out the strength of this effect, though it appears less sharply in his work because he defines the life cycle on age of the head of the household.

${ }^{32}$ Data on spending on child care available in the HES are unreliable because in many cases care is provided by a family member, typically a grandparent, due to lack of access to affordable high quality formal care.
} 
consumption to the adults and children as outlined in the preceding section, and we treat the costs of children as a lump sum transfer. This leaves for estimation a within-period production and aggregate demand system for the two adults in the household. We use the estimated parameters of this system to test our capital market hypothesis.

\subsection{Within-period production and demand system}

To satisfy the required aggregation conditions and for the purpose of simplification we estimate a model in which the time each partner spends on leisure and on household production is, in each case, treated as an input to the production of a good consumed by both partners. We specify a Cobb-Douglas production function for both activities and estimate the production shares for leisure, $z$, and for the domestic good, $y$, as

$$
\begin{gathered}
s_{z}=\sigma_{z}+\xi_{z} \\
s_{y}=\sigma_{y}+\xi_{y}
\end{gathered}
$$

where $s_{z}=w_{f} z_{f} f\left(w_{f} z_{f}+w_{m} z_{m}\right), \quad s_{y}=w_{f} t_{f} /\left(w_{f} t_{f}+w_{m} t_{m}\right)$, and $\xi_{z}, \xi_{y}$ are stochastic error terms. Within-period prices, $q$ and $p$, are specified in the demand system as functions of wage rates, production parameters and the error term for each record. ${ }^{33}$ This specification of the production system constructs data for the missing price variables on the assumption that households with larger female production shares due to specialisation face lower prices because they are more productive.

We select the Almost Ideal Demand System for estimation of within-period preference parameters. Suppressing the household type and phase subscripts, the indirect utility function for adult $i, i=1,2$, takes the form

$$
u_{i}\left(q, p, c_{i}\right)=\left(\ln c_{i}-\ln a_{i}(q, p)\right) / b_{i}(q, p)
$$

where $c_{i}$ is adult $i$ 's full consumption expenditure. The price indexes $a_{i}(q, p)$ and $b_{i}(q, p)$ are given by

$$
\begin{gathered}
\ln a(q, p)=\alpha_{0}+\alpha_{z} \ln q+\alpha_{y} \ln p+0.5 \gamma_{z z} \ln ^{2} q+\gamma_{z y} \ln q \ln p+0.5 \gamma_{y y} \ln ^{2} p \\
\ln b(q, p)=\beta_{z} \beta_{y} \ln q \ln p
\end{gathered}
$$

where $\alpha_{0}, \alpha_{j}, \gamma_{j l}$ and $\beta_{j}, j, l=x, y, z$, are parameters and the $\alpha_{j}$ contain a dummy variable for the presence of dependent children. The restrictions for adding up are $\sum \alpha_{j}=1, \sum \beta_{j}=0$ and $\Sigma \gamma_{j l}=0$, for symmetry, $\gamma_{j l}=\gamma_{l j}$, and for homogeneity, $\sum \gamma_{j l}=0$. Household demands in share form are

$$
\begin{aligned}
& S_{z}=\alpha_{z}+\gamma_{z z} \ln q+\gamma_{z y} \ln p+\beta_{z} \ln (c / a(q, p))+\varepsilon_{z} \\
& S_{y}=\alpha_{y}+\gamma_{y y} \ln p+\gamma_{y z} \ln q+\beta_{y} \ln (c / a(q, p))+\varepsilon_{y} \\
& S_{x}=\alpha_{x}+\gamma_{x z} \ln q+\gamma_{x y} \ln p+\beta_{x} \ln (c / a(q, p))+\varepsilon_{x}
\end{aligned}
$$

\footnotetext{
${ }^{33}$ With this specification there is the potential for parameter bias due to the endogeneity of time allocations. However, with missing data on domestic output there is inevitably a trade-off between this problem and parameter bias due to omitted domestic price variables.
} 
where $S_{x}=x / c, S_{z}=q z / c$ and $S_{y}=p y / c$, and $c=\sum c_{i}, i=1,2$, and the error terms $\varepsilon_{z}, \varepsilon_{y}, \varepsilon_{x}$, can be interpreted to represent variation in productivities or preferences. Given adding up, we can drop the share equation for the market good. We estimate the production system and share equations for leisure and the domestic good on data for households in phase 1. The sample is selected on the criteria that the male partner reports positive hours and neither partner has negative earned or unearned incomes. ${ }^{34}$

\subsection{Intertemporal demand system}

The six phases of the household's life cycle vary in length in terms of number of years and we take account of this by discounting on an annual basis. We therefore have: Phase 1: $\phi_{1}=\left\{t \mid t=0, \ldots, \tau_{1}\right\}$, Phase 2: $\phi_{2}=\left\{t \mid t=\tau_{1}+1, \ldots, \tau_{2}\right\}$, Phase 3: $\phi_{3}=\left\{t \mid t=\tau_{2}+1, \ldots, \tau_{3}\right\}$, Phase 4: $\phi_{4}=\left\{t \mid t=\tau_{3}+1, \ldots, \tau_{4}\right\}$, Phase 5: $\phi_{5}=$ $\left\{t \mid t=\tau_{4}+1, \ldots, \tau_{5}\right\}$, Phase 6: $\phi_{6}=\left\{t \mid t=\tau_{5}+1, \ldots, \tau_{6}\right\}$, where $t$ denotes the year. We assume that within each given phase, the parameters of the utility functions, as well as the household welfare weights, remain constant, though they may change between phases. The subscript $j=1, \ldots, 6$ refers to the phase. Introducing the phase subscripts into the above indirect utility function we can write it as

$$
u_{t}=\hat{a}_{j}\left(q_{t}, p_{t}\right)+\frac{\ln c_{t}}{b_{j}\left(q_{t}, p_{t}\right)} \quad t \in \phi_{j}, j=1, \ldots, 6
$$

with

$$
\hat{a}_{j}\left(q_{t}, p_{t}\right) \equiv \frac{-\ln a\left(q_{t}, p_{t}\right)}{b_{j}\left(q_{t}, p_{t}\right)}
$$

The solution to the household's problem yields the life cycle profile of full income, and the parameters of the within period demand functions are used to derive profiles of market and domestic consumption, saving and secondary earner labor supplies, for the perfect and imperfect capital market models respectively.

\subsection{Perfect capital market}

Given the assumed functional form for indirect utility, the first order conditions for this problem in the perfect capital market case are

$$
\begin{gathered}
\frac{\rho^{t}}{\delta^{t} b_{j}\left(q_{t}, p_{t}\right) c_{t}}=\lambda \quad t \in \phi_{j}, j=1, \ldots, 6 \\
\sum_{t=0}^{T} \delta^{t} c_{t}=W \equiv \sum_{t=0}^{T} \delta^{t}\left(A \sum_{i=1}^{2} w_{i t}+P_{t}\right)
\end{gathered}
$$

where $W$ is "full wealth". The important thing to note is that the marginal utility of full consumption expenditure in each period depends on the prices of the domestic

\footnotetext{
34 The results are available on request from the authors.
} 
good, $p_{t}$, and leisure, $q_{t}$, and therefore on the wage rates and the domestic productivity. Thus the entire time profile of full consumption, as well as its allocation within each period as between market and domestic consumption, depends on this productivity. The solution of the system is given very simply by

$$
\begin{gathered}
c_{t}=\alpha_{t} c_{T} \\
c_{T}=\frac{W}{\sum_{t=0}^{T-1} \delta^{t} \alpha_{t}+\delta^{T}} \\
\alpha_{t} \equiv\left(\frac{\rho}{\delta}\right)^{t-T} \frac{b_{6}\left(q_{\left.T, p_{T}\right)}\right.}{b_{j}\left(q_{t}, p_{t}\right)} \quad t \in \phi_{j}, j=1, \ldots, 5
\end{gathered}
$$

\subsection{Imperfect capital market}

In principle, this problem could be fairly complicated to solve. However, from the data, we can establish that, at the margin, the average household is in equilibrium in the capital market at the saving interest rate in phases 5 and 6 , and at borrowing interest rates in phases $1-4$. It can also be established from the data that the latter interest rates are higher than the former. Denoting the discount factors by $\delta(t, j)$, $j=1, \ldots, 6, t=0, \ldots, T$, we can use these to collapse the single period budget constraints into a lifetime wealth constraint, which we write as

$$
\sum_{t, j} c_{t} \delta(t, j)=W
$$

where wealth $W$ is computed from the full income data and the discount rates. The household again maximises utility subject to this wealth constraint, yielding the first order conditions

$$
\frac{\rho^{t}}{\delta(t, j) b_{j}\left(q_{t}, p_{t}\right) c_{t}}=\lambda \quad t \in \phi_{j}, j=1, \ldots, 6
$$

together with the wealth constraint. We then have to solve the equations

$$
\begin{gathered}
c_{t}=\hat{\alpha}_{t} c_{T} \\
c_{T}=\frac{W}{\sum_{t, j} \delta(t, j) \hat{\alpha}_{t}+\delta(T, 6)} \\
\hat{\alpha}_{t} \equiv \frac{\rho^{t-T} \delta(T, 6) b_{6}\left(q_{\left.T, p_{T}\right)}\right.}{\delta(t, j) b_{j}\left(q_{t}, p_{t}\right)} j=1, \ldots, 5
\end{gathered}
$$

for the optimal time path of total income.

\subsection{Intertemporal profiles}

Equations $(34,35,36)$ show how the optimal path of life cycle full consumption expenditure, $c_{t}, t \in \phi_{j}, j=1, \ldots, 6$, depends on the marginal utility of consumption in each phase, as a function of the discount factors $\delta(t, j), t=0, \ldots, T$, and the price index $b_{j}\left(q_{t}, p_{t}\right)$, where $p_{t}$ and $q_{t}$ are functions of wage rates and production system 
parameters. We select discount rates consistent with this hypothesis based on data indicating that the majority of households in the earlier phases, and particularly those in the phase 2, borrow short term at an interest rate above the lending rate.

To evaluate the alternative capital market models we test how well life cycle profiles of consumption generated by the data can be replicated using the estimated preference parameters and selected discount rates. The first step is the construction of reference consumption profiles for the two adults. For this we first compute full consumption $c_{t}, t \in \phi_{j}, j=1, \ldots, 6$, using data means for time allocations, wage rates and the tax-benefit system in each phase, and median saving in phases 1-5. Consumption in phase 6 is obtained by compounding up previous saving/borrowing in each year of each phase at the relevant interest rate. We then compute reference consumption profiles for the market good and for market plus domestic output using the full set of the within-phase demand system parameters and prices. Reference profiles at the level of the household are obtained by adding the reference costs of children across phases $2-4$. We select a lending rate of 2.1 per cent and a time preference rate of 2.0 per cent.

In the perfect capital market model the borrowing interest rate is set equal to the lending rate of 2.1 per cent. In the imperfect capital market model consumptions profiles are derived for real borrowing rates of 2.3, 3.4, 3.3 and 2.8 in phases $1-4$, respectively. Though these rates may appear low in absolute terms, they are much higher than the lending interest rate. It is also important to keep in mind that they represent across-household averages, and that there is considerable heterogeneity across households in saving/borrowing behavior within each phase, particularly in the early phases. Most households will in fact face either much higher or lower rates.

We compare the reference consumption profiles with those generated by the perfect and imperfect capital markets models using the same data means for time allocations, wage rates, taxes and benefits, and the saving profiles generated by the models. Again, the preference parameters, $\beta_{j}, j=z, y, x$, are applied to obtain $c_{t}$ for each model (as set out in (29-31) and in (34-36), respectively) and the full set of within-period demand system parameters and prices are then used to predict market, domestic and leisure expenditures. Figure 5a compares graphically the life cycle profiles for the full consumption of the adults generated by the perfect and imperfect capital market models with the reference profile. The adults' full consumption profile under the imperfect capital market hypothesis is strongly U-shaped, consistent with the reference profile. In contrast, the perfect capital market model predicts that the household will smooth adult full consumption.

Figure $6 \mathrm{a}$ and $\mathrm{b}$ compare the life cycle profiles of market and of market plus domestic goods consumptions generated by the perfect and imperfect capital market models with the corresponding reference profiles. Again the profiles for the imperfect capital market closely match the reference profiles. Adult consumption of the market good ("mkt") and of the market plus domestic good ("mkt+hhp") are strongly U-shaped. Moreover, because the perfect capital market model generates a relatively smooth profile for the adults' consumptions, including the costs of children results in more strongly humped shaped profiles than those indicated by the data. In other words, evidence of more humped profiles for household consumption 


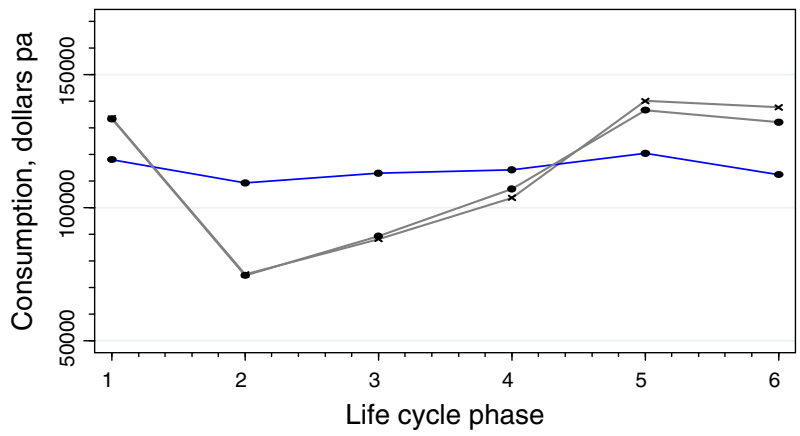

$\begin{array}{lll}\longrightarrow \times & \text { Reference } \\ \longrightarrow & \text { Imperfect capital market }\end{array}$

Fig. 5 Adult full consumption
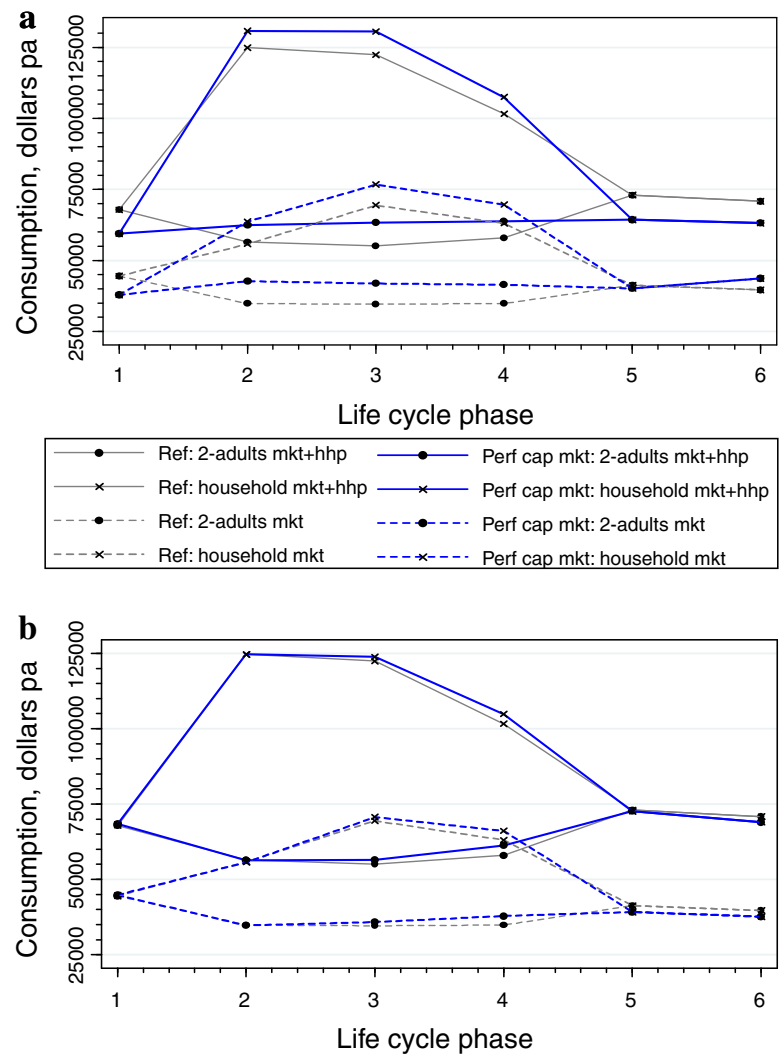

\begin{tabular}{|c|c|c|c|}
\hline$\bullet$ & dults mkt+hhp & $\longrightarrow$ & Imperf \\
\hline & Ref: household mkt+hhp & & Imperf cap mkt: ho \\
\hline & Ref: & & kt \\
\hline & Ref: hous & & o mkt: household mkt \\
\hline
\end{tabular}

Fig. 6 a Perfect capital market. b Imperfect capital market 
of the market good and of market plus household production across the phases in which children are present is required to support the perfect capital market hypothesis. The imperfect capital market model depicted in Figure $6 \mathrm{~b}$ clearly predicts the data far better.

\section{Conclusions}

Our descriptive picture of a household's life cycle time allocation, income and consumption, defined in terms not of calendar years, but of key phases in the evolution of the family, helps resolve some of the "puzzles" that have been noted in the existing literature, but suggests a new one: Why, in the phase in which the household has pre-school children, are there such dramatic changes in time allocations, consumption and saving? The data on borrowing and interest rates suggest that the standard assumption of a perfect capital market is untenable, but so is the hypothesis that households do not borrow short-term. By modelling household life cycle choices under respectively perfect and imperfect capital markets, we show that in the former case we cannot reasonably explain the data, in the latter case we can. More generally, we are proposing an approach to life cycle saving and consumption behavior which sees the endogenisation of the income process via female labor supply choices as essential.

Our results have interesting implications for public policy, at a time when declining fertility is seen as the major cause of population ageing and consequential problems in sustaining social security programmes, such as pay-as-you-go pension systems. A return to an individual based family tax system together with support for children during the critical early childhood phase, essentially through public sector child care and an education system suitably adapted for the age of the child, could help overcome the problems presented by an imperfect capital market and reduce the costs of having children. This should be a fruitful area for future research.

Acknowledgement This research was supported under Australian Research Council's Discovery Project funding scheme (DPØ881787).

Open Access This article is distributed under the terms of the Creative Commons Attribution Noncommercial License which permits any noncommercial use, distribution, and reproduction in any medium, provided the original author(s) and source are credited.

\section{References}

Aguiar, M., \& Hurst, E. (2005). Consumption vs expenditure. Journal of Political Economy, 113(5), 919948.

Ando, A., \& Modigliani, F. (1963). The "life cycle"hypothesis of saving: Aggregate implications and tests, American Economic Review, 53, 55-84.

Apps, P. F., Long, N. V., \& Rees, R. (2009). Optimal piecewise linear income taxation, CESifo Working Paper No 2565.

Apps, P. F., \& Rees, R. (2001). Household production, full consumption and the costs of children. Labour Economics, 8, 621-648. 
Apps, P. F.,\& Rees, R. (2009). Public Economics and the Household. Cambridge: Cambridge University Press.

Attanasio, O. P., \& Banks, J. (1998). Trends in household saving: A tale of two countries, Working Paper Series No W98/15, Institute of Fiscal Studies, London.

Attanasio, O. P., \& Browning, M. (1995). Consumption over the life cycle and over the business cycle. American Economic Review, 85, 1118-1137.

Attanasio, O. P., Low, H. \& Sanchez-Marcos, V. (2003). Explaining changes in female labour supply in a life-cycle model, NBER Summer Institute Session on: Aggregate Implications of Microeconomic Consumption Behavior, Boston, July 21-25.

Australian Bureau of Statistics. (2001). Government benefits, taxes and household Iincome, Cat No 6537.0, ABS, Canberra.

Banks, J., Blundell, R., \& Tanner, S. (1998). Is there a retirement saving puzzle? American Economic Review, 88(4), 769-788.

Baxter, M., \& Jermann, U. J. (1999). Household production and the excess sensitivity of consumption to current Income. American Economic Review, 89(4), 902-920.

Blundell, R., Browning, M., \& Meghir, C. (1994). Consumer demand and the life-cycle allocation of household expenditures. Review of Economic Studies, 61, 57-80.

Browning, M., \& Crossley, T. (2001). The life cycle model of consumption and saving. Journal of Economic Perspectives, 15(3), 46-60.

Browning, M., \& Lusardi, A. (1996). Household saving: Micro theories and micro facts. Journal of Economic Literature, XXXIV, 1797-1855.

Browning, M., \& Ejrnaes, M. (2002). Consumption and Children. CAM Discussion Paper 2002-2006, University of Copenhagen.

Carroll, C. D. (1992). The buffer stock theory of saving: Some macroeconomic evidence. Brookings Papers on Economic Activity, pp. 61-156.

Carroll, C. D. (1994). How does future income affect current consumption?. The Quarterly Journal of Economics, CIX, 111-148.

Carroll, C. D. (1997). Buffer stock saving and the life cycle/permanent Income hypothesis, The Quarterly Journal of Economics, CXII, 1-55.

Carroll, C. D. (2001). A theory of the consumption function, with and without liquidity constraints. Journal of Economic Perspectives, 15(3), 23-46.

Deaton, A. (1992). Understanding consumption. Oxford: Clarendon Press.

Erosa, A., \& Gervais, M. (2002). Optimal taxation in life-cycle economies. Journal of Economic Theory, $105,338-369$.

Friedman, M. (1957). A theory of the consumption function. Princeton NJ: Princeton University Press for NBER.

Fortin, N. (1995). Allocation inflexibilities, female labour supply and housing asset accumulation: Are women working to pay the mortgage?Journal of Labour Economics, 13(3), 524-557.

Gourinchas, P.-O., \& Parker, J. A. (2002). Consumption over the life cycle. Econometrica, 70, 47-89.

Gronau, R., (1980). Home production-A forgotten industry. Review of Economics and Statistics, 62(3), $26-42$.

Heathcote, J., Storesletten, K. \& Violante, G. L. (2008). The macroeconomic implications of rising wage inequality in the United States, CEPR WP, p. 4296.

Heckman, J. (1974). Life cycle consumption and labor supply. American Economic Review, 64, 188-194.

le Blanc, D., \& Wolff, F.-C. (2006). Leaving home in Europe: The role of parents' and children's incomes. Review of Economics of the Household, 4(1), 53-73.

Shaw, K. (1994). The persistence of female labor supply: Empirical evidence and implications. Journal of Human Resources, 29, 348-378. 